\title{
Differential Sensitivity to Boscalid in Conidia and Ascospores of Didymella bryoniae and Frequency of Boscalid-Insensitive Isolates in South Carolina
}

\author{
Anthony P. Keinath, Clemson University, Coastal Research and Education Center, Charleston, SC 29414-5329
}

\begin{abstract}
Keinath, A. P. 2012. Differential sensitivity to boscalid in conidia and ascospores of Didymella bryoniae and frequency of boscalid-insensitive isolates in South Carolina. Plant Dis. 96:228-234.

Since 2003, a 2:1 mixture of the fungicides boscalid and pyraclostrobin (Pristine) has been used widely on watermelon and other cucurbits, primarily to control gummy stem blight caused by Didymella bryoniae. Several isolates of D. bryoniae that were insensitive to boscalid at 10 $\mathrm{mg} / \mathrm{liter}$ were found in a watermelon research plot in South Carolina in 2008. In total, 201 isolates collected between 1998 and 2009 were tested for sensitivity to boscalid by determining percentage germination of ascospores and conidia on media amended with boscalid at 0.01 to $10.0 \mathrm{mg} /$ liter. All 31 isolates collected in 1998, 2002, or 2005 were sensitive to boscalid. Of the 170 isolates collected in or after 2006, $84.7 \%$ were insensitive to boscalid, including 19 of 30 isolates recovered from greenhouse-grown seedlings. The oldest insensitive isolates were obtained in 2006 from a greenhouse and in 2008 from a commercial field. Ascospores were less sensitive to boscalid than conidia. With boscalid at $1.0 \mathrm{mg} / \mathrm{liter}, 22.4 \%$ of ascospores but only $4.1 \%$ of conidia

of 31 sensitive isolates germinated. Similarly, a mean of $68.6 \%$ of the ascospores and $54.1 \%$ of the conidia of 120 insensitive isolates germinated at 1.0 and $10.0 \mathrm{mg} /$ liter. The $50 \%$ effective concentration $\left(\mathrm{EC}_{50}\right)$ values based on ascospore germination were two to three times higher than values based on conidia germination. The significance of miscalculating $\mathrm{EC}_{50}$ values by considering only conidia was demonstrated in a greenhouse experiment. Twelve isolates that were sensitive, moderately insensitive, or highly insensitive based on conidia germination did not differ in relative virulence on boscalid-treated muskmelon seedlings when inoculum suspensions comprised ascospores alone or ascospores and conidia. This is the first report of differential sensitivity to a fungicide between conidia and ascospores in D. bryoniae. Because $D$. bryoniae produces conidia and ascospores on diseased hosts, both spore types should be used when calculating $\mathrm{EC}_{50}$ values for boscalid.
\end{abstract}

Didymella bryoniae (Fuckel) Rehm (anamorph Stagonosporopsis cucurbitacearum (Fr.) Aveskamp, Gruyter \& Verkley [5] [synonym Phoma cucurbitacearum (Fr.) Sacc.]) is the ascomycete that causes gummy stem blight and black rot of cucurbits. The fungus is homothallic, in that isolates are capable of producing ascospores without pairing with another isolate of a different mating type (9). Although variation among isolates has been observed (9), most isolates have the ability to produce ascospores (26). Pseudothecia with characteristic two-celled ascospores readily form on diseased cucurbit tissues $(10,20,45)$. Ascospores of $D$. bryoniae have been trapped above watermelon (Citrullus lanatus (Thunb.) Matsum. \& Nakai var. lanatus) fields in which the plants had symptoms of gummy stem blight (33). When spores were sampled year-round, ascospores were detected primarily after symptoms of gummy stem blight appeared (34).

The primary method to manage gummy stem blight is protection of cucurbit plants by application of fungicides (16). Strobilurin fungicides, such as azoxystrobin (a methoxy-acrylate) and pyraclostrobin (a methoxy-carbamate), belong to the quinone-outside inhibitor (QoI) cross-resistance group, also known as Fungicide Resistance Action Committee (FRAC) group 11. Their mode of action is binding to ubiquinol oxidase in the electron transport chain in mitochondria, which inhibits fungal respiration (6). Isolates of $D$. bryoniae insensitive to strobilurin fungicides were found in Delaware, Maryland, and Georgia in 2000 (31,39); South Carolina in 2001 (19); and Texas in 2003 (30).

Corresponding author: A. P. Keinath, E-mail: tknth@clemson.edu

Technical Contribution Number 5950 of the Clemson University Experiment Station.

Accepted for publication 6 September 2011.

http://dx.doi.org/10.1094/PDIS-06-11-0490

(C) 2012 The American Phytopathological Society
Boscalid is a pyridine-carboxamide, one of the chemical classes in FRAC group 7, which inhibits fungal respiration by binding to the enzyme succinate dehydrogenase in mitochondria $(3,4,27)$. A 2:1 mixture of the fungicides boscalid and pyraclostrobin (Pristine 38WG; BASF Corporation, Research Triangle Park, NC) was registered for use on cucurbits by the United States Environmental Protection Agency in 2003. By 2004, Pristine was applied an average of 1.8 times per year to 25 to $54 \%$ of the U.S. watermelon crop (42). In some states, Pristine was recommended as the best fungicide against gummy stem blight (1). The main reason for the widespread use of Pristine was that the boscalid component controlled strobilurin-insensitive isolates of $D$. bryoniae (35). Insensitivity to boscalid in $D$. bryoniae was detected first in Georgia in research plots and commercial fields of watermelon in $2007(29,38)$ and subsequently in research plots of watermelon in South Carolina in 2008 (25). Boscalid-insensitive isolates of D. bryoniae also have been found in Indiana (12).

In a preliminary experiment with 16 isolates of $D$. bryoniae that included a mix of boscalid-sensitive and -insensitive isolates, it was noted that more ascospores than conidia germinated in the presence of boscalid (25). Because ascospores are airborne but conidia are primarily splash dispersed, a difference in fungicide sensitivity of ascospores versus conidia may have important implications for the epidemiology of gummy stem blight $(33,34)$. The potential differential sensitivity of the two spore types was investigated while a collection of isolates was screened for sensitivity to boscalid. The objectives of this study were to determine (i) if ascospores and conidia of $D$. bryoniae differ in sensitivity to boscalid, (ii) if differential sensitivity of ascospores and conidia affect $50 \%$ effective concentration $\left(\mathrm{EC}_{50}\right)$ calculations for determining sensitivity to boscalid, and iii) how frequently boscalid-insensitive isolates occur in South Carolina.

\section{Materials and Methods}

Isolate collection. In June 2009, four farms producing watermelon were sampled in Bamberg, Barnwell, Colleton, and Hampton Counties, SC. Bamberg, Colleton, and Barnwell Counties were 
among the four South Carolina counties with the largest watermelon acreage in 2007 (43). The field in Bamberg received two applications of Pristine approximately 3 weeks apart. The other three fields also were sprayed with Pristine one or more times during the 2009 growing season. Fifty leaves showing leaf spots of gummy stem blight were randomly selected from one field on each farm. Twenty-five leaves also were collected from a research plot of watermelon at the Clemson University Edisto Research and Education Center, Barnwell County, SC on 25 June. The research plot was included because the detailed fungicide history of the plot was available. In 2009, it received applications of Pristine on 19 May and 5 June.

Isolates of $D$. bryoniae were obtained by culturing from one lesion per leaf. Small pieces of leaf tissue from the margins of lesions were surface disinfested in $0.6 \%$ sodium hypochlorite for 1 $\mathrm{min}$, rinsed in sterile deionized water, blotted dry on paper towels, and placed onto one-quarter-strength potato dextrose agar (QPDA) amended after autoclaving with $100 \mathrm{mg}$ of chloramphenicol, 100 $\mathrm{mg}$ of streptomycin sulfate, and $60.5 \mathrm{mg}$ of metalaxyl $(0.25 \mathrm{ml}$ Ridomil 2E) per liter (17). Plates were held at 23 to $25^{\circ} \mathrm{C}$ with a 16-h photoperiod for 2 to 3 days until pycnidia typical of $D$. bryoniae were produced. In all, 135 single-conidium cultures were stored on dried filter paper at $5^{\circ} \mathrm{C}(28)$.

In total, 201 isolates were selected for testing in four groups based on their previous field exposure to boscalid-containing fungicide. To determine baseline sensitivity, 15 isolates from a watermelon field in Hampton County collected in May and June 1998 and 6 isolates from muskmelon vines in a field in Florence County, SC, collected in August 2002 were used. These 21 isolates were not previously exposed to strobilurins or boscalid (Table 1) $(18,19)$. Ten isolates collected in July 2005 from two watermelon fields in Barnwell and Hampton Counties represented limited exposure to boscalid for two to three seasons (19). The Barnwell field received three applications of Pristine and the Hampton field received more than one application of Pristine in 2005. In the third group, isolates collected in summer 2009 in South Carolina represented repeated exposure to Pristine. All of the fields sampled in Hampton County in 1998, 2005, and 2009 belonged to the same grower (Table 1). The fourth group included isolates collected after Pristine was registered but it was not known whether the isolates were exposed to boscalid. In 2006, 11 isolates were collected from pollenizer watermelon seedlings with necrotic cotyledons, and 19 isolates were collected in 2009 from watermelon seedlings with symptoms of gummy stem blight (19). In addition, four isolates recovered in May 2008 from watermelon grown in Bamberg County and one isolate recovered from watermelon in July 2008 in
Barnwell County were tested for sensitivity to boscalid; whether they had been exposed to boscalid was unknown.

Boscalid sensitivity. Boscalid (99.5\% technical grade) was dissolved in acetone to make a $10 \mathrm{mg} /$ liter stock solution (2). Aliquots of the stock solution were added to autoclaved water agar ( $20 \mathrm{~g}$ of agar per liter) for concentrations of boscalid at 0.01, 0.1, 1.0, and $10 \mathrm{mg} / \mathrm{liter}$, and dispensed into $15-\mathrm{mm}$ petri dishes (2). Control media received only acetone at $1.0 \mathrm{ml} /$ liter. Isolates were grown from a 0.5 -by-0.5-cm piece of colonized filter paper onto QPDA in petri dishes that were not sealed with Parafilm and held at 23 to $25^{\circ} \mathrm{C}$ with a 16 -h photoperiod for 10 to 14 days (19). Cultures were flooded with $5 \mathrm{ml}$ of sterile water and scraped gently to release conidia and ascospores. The spore suspension was poured through four layers of cheesecloth, and $0.2 \mathrm{ml}$ of the filtrate was spread on boscalid-amended media. Plates were incubated for $24 \mathrm{~h}$ at 23 to $25^{\circ} \mathrm{C}$ with a 16 -h photoperiod. At $\times 100$ magnification, 100 conidia and 50 ascospores were examined on each plate for germination. A germinated spore had a germ tube longer than the length of the conidium or one ascospore cell. Spores with germ tubes shorter than the length or no germ tube present at all were counted as nongerminated. Two plates per fungicide concentration were prepared for each isolate, and each isolate was tested twice in separate trials (2). Relative germination was calculated per plate per trial for each isolate and spore type by dividing the number of spores that germinated on fungicide-amended medium by the mean number of spores that germinated on nonamended medium (19). Isolates with an $\mathrm{EC}_{50} \leq 1.0 \mathrm{mg} / \mathrm{liter}$ were considered to be sensitive, isolates with an $\mathrm{EC}_{50}>1.0$ and $\leq 10.0 \mathrm{mg} /$ liter were considered moderately insensitive, and isolates with an $\mathrm{EC}_{50}>10.0$ $\mathrm{mg} /$ liter were highly insensitive.

Greenhouse experiments. Six isolates collected in 2009 from the farm in Bamberg County and six isolates collected in 2009 from the farm in Barnwell County that differed in boscalid $\mathrm{EC}_{50}$ values based on relative conidial germination were used in the greenhouse experiments. Because of space limitations in the greenhouse, the 12 isolates were tested in two groups with 3 isolates from each farm in each group. Within each group, two isolates (one from each farm) were judged to be highly insensitive and the other four isolates were sensitive or moderately insensitive to boscalid in vitro (Table 2). Each group of isolates was tested twice in separate trials. Muskmelon (Cucumis melo subsp. melo 'Classic') seedlings were transplanted into 10 -cm-diameter pots, three uniform seedlings per pot. The experimental design was a split plot, with isolate as the whole plot and fungicide as the subplot, with three replications. Control treatments included noninoculated seedlings treated with fungicides or water, also replicated three times. When seed-

Table 1. The 50\% effective concentration $\left(\mathrm{EC}_{50}\right)$ values calculated by linear regression of probit-transformed relative germination of ascospores, conidia, or both spore types of Didymella bryoniae on water agar amended with four concentrations of boscalid

\begin{tabular}{|c|c|c|c|c|c|c|c|c|c|c|c|}
\hline \multirow[b]{2}{*}{ Location $^{y}$} & \multirow[b]{2}{*}{ Exposure $^{\mathrm{z}}$} & \multirow[b]{2}{*}{ Year } & \multirow[b]{2}{*}{$N$} & \multirow[b]{2}{*}{ Spore type } & \multicolumn{4}{|c|}{$\mathbf{E C}_{50}(\mathrm{mg} / \text { liter })^{\mathrm{w}}$} & \multicolumn{3}{|c|}{ Sensitivity $^{x}$} \\
\hline & & & & & Mean \pm SD & Median & Min & Max & $\mathbf{S}$ & $\mathbf{M}$ & $\mathbf{H}$ \\
\hline \multirow[t]{3}{*}{ Hamp and Flo, fields } & None & 1998-2002 & 21 & Ascospores & $0.26 \pm 0.092$ & 0.25 & 0.13 & 0.45 & 21 & 0 & 0 \\
\hline & $\ldots$ & $\ldots$ & $\ldots$ & Conidia & $0.13 \pm 0.059$ & 0.10 & 0.057 & 0.26 & 21 & 0 & 0 \\
\hline & & & $\ldots$ & Both & $0.18 \pm 0.071$ & 0.17 & 0.09 & 0.33 & 21 & 0 & 0 \\
\hline \multirow[t]{3}{*}{ Hamp and Barn, fields } & Limited & 2005 & 10 & Ascospores & $0.24 \pm 0.11$ & 0.22 & 0.12 & 0.48 & 10 & 0 & 0 \\
\hline & $\ldots$ & $\ldots$ & $\ldots$ & Conidia & $0.094 \pm 0.078$ & 0.06 & 0.046 & 0.28 & 10 & 0 & 0 \\
\hline & & $\ldots$ & $\ldots$ & Both & $0.15 \pm 0.090$ & 0.12 & 0.08 & 0.37 & 10 & 0 & 0 \\
\hline \multirow{3}{*}{ South Carolina greenhouse } & Unknown & 2006 & 11 & Ascospores & $>10.0$ & 0.23 & 0.15 & $>10$ & 7 & 2 & 2 \\
\hline & $\ldots$ & $\ldots$ & $\ldots$ & Conidia & $1.42 \pm 2.70$ & 0.11 & 0.072 & 8.17 & 8 & 3 & 0 \\
\hline & $\ldots$ & $\ldots$ & $\ldots$ & Both & $4.93 \pm 12.0$ & 0.16 & 0.033 & $>10$ & 8 & 2 & 1 \\
\hline \multirow[t]{3}{*}{ South Carolina greenhouse } & Unknown & 2009 & 19 & Ascospores & $>10.0$ & $>10.0$ & 0.20 & $>10$ & 3 & 3 & 13 \\
\hline & $\ldots$ & $\ldots$ & $\ldots$ & Conidia & $>10.0$ & $>10.0$ & 0.12 & $>10$ & 4 & 4 & 11 \\
\hline & $\ldots$ & & & Both & $>10.0$ & $>10.0$ & 0.16 & $>10$ & 3 & 4 & 12 \\
\hline \multirow[t]{3}{*}{ Hamp, Bam, Barn, Coll; fields } & Repeated & 2009 & 37 & Ascospores & $4.71 \pm 2.72$ & 4.43 & 0.82 & 10.24 & 3 & 32 & 2 \\
\hline & $\ldots$ & $\ldots$ & $\ldots$ & Conidia & $1.08 \pm 0.84$ & 0.86 & 0.18 & 4.58 & 23 & 14 & 0 \\
\hline & $\ldots$ & $\ldots$ & $\ldots$ & Both & $2.13 \pm 1.29$ & 1.95 & 0.39 & 5.33 & 9 & 28 & 0 \\
\hline
\end{tabular}

${ }^{\mathrm{w}} \mathrm{SD}=$ standard deviation, Min = minimum, and Max = maximum.

${ }^{x}$ Sensitive $(\mathrm{S}), \mathrm{EC}_{50} \leq 1.0 \mathrm{mg} /$ liter; moderately insensitive $(\mathrm{M}), \mathrm{EC}_{50}>1.0 \mathrm{mg} / \mathrm{liter}$ and $\leq 10.0$; and highly insensitive $(\mathrm{H}), \mathrm{EC}_{50}>10.0 \mathrm{mg} / \mathrm{liter}$.

y Hampton (Hamp), Florence (Flo), Barnwell (Barn), Bamberg (Bam), and Colleton (Coll) Counties in South Carolina; greenhouse or field.

z Exposure to boscalid. 
lings had two fully expanded true leaves, seedlings were sprayed with boscalid (Endura) at $0.28 \mathrm{~g} /$ liter, pyraclostrobin (Cabrio 20EG) at $0.14 \mathrm{~g} /$ liter, boscalid + pyraclostrobin (Pristine 38WG) at $0.43 \mathrm{~g} /$ liter, or water with a handheld pump-pressurized sprayer. The rate of boscalid + pyraclostrobin was equivalent to the labeled rate per 935 liters of water applied per hectare, and the rates of boscalid and pyraclostrobin were equivalent to the amounts of these two fungicides in Pristine.

One day later, seedlings were inoculated with a suspension of 1 to $2 \times 10^{6}$ ascospores and conidia per milliliter of sterile sucrosecasein solution (7). Inoculum consisted of only ascospores for three isolates and a mix of ascospores and conidia for nine isolates. Ascospores represented $\geq 65 \%$ of the spores in the suspensions for eight of the nine isolates (Table 2). Inoculum was applied with a handheld pump-pressurized sprayer that delivered approximately 1 $\mathrm{ml}$ per seedling. Noninoculated control seedlings were sprayed with sterile sucrose-casein solution. Seedlings were held at $100 \%$ relative humidity for $72 \mathrm{~h}$. Three days after inoculation, percentage of diseased foliage for each plant was rated visually by assigning a rating from a 16-point Horsfall-Barratt-type rating scale, where $0=$ $0,7=45$, and $15=100 \%$ (22). The midpoint percentage of each rating was used for data analysis. A percent mean disease severity for each pot (experimental unit) was calculated. To account for differences in virulence among individual isolates, relative disease severity was calculated as the percent disease severity on fungicide-treated seedlings divided by the percent disease severity on the inoculated water control (19). Disease severity was used to compare fungicide treatments with the nontreated control, and relative disease severity was analyzed to compare fungicides after correcting for possible differences in virulence among isolates (26).

Statistical analysis. All spore germination data sets exhibited equality of variances between the two repeated tests based on twotailed $F$ tests of mean square error terms $(P=0.025)$; therefore, data were combined for analysis (37). Relative germination data were transformed with the arcsine square root before analysis of variance to reduce inequality of variances among treatments. PROC MIXED of SAS (version 9.1; SAS, Inc., Cary, NC) was used to examine the effects of spore type and isolate as fixed effects and replication nested within trial (i.e., repetition of an experiment) as a random effect. When relative spore germination was plotted against the base-10 logarithm of boscalid concentration, plots for most isolates were not linear. Relative spore germination was probit transformed and regressed against the base-10 loga- rithm of the boscalid concentration using PROC GLM of SAS $(19,39)$. The resulting linear regression equations were solved to calculate the concentration of boscalid at which the relative responses were reduced to $50 \%$ of the value of the nonamended control $\left(\mathrm{EC}_{50}\right)$. Because of significantly higher germination of ascospores compared with conidia on boscalid-amended medium, germination data from ascospores, conidia, and both spore types were used to calculate $\mathrm{EC}_{50}$ values. With greenhouse data, disease severity and relative disease severity percentages were transformed by calculating the arcsine square root before analysis of variance to reduce inequality of variances among treatments. PROC MIXED of SAS was used to examine the effects of trial, isolate, fungicide, and their interactions as fixed effects and replication nested within trial-isolate as a random effect (19).

\section{Results}

Spore germination on boscalid-amended medium. All 21 baseline isolates, which were collected in 1998 from watermelon or in 2002 from muskmelon, were sensitive to boscalid. A mean of $99.8 \%$ of the ascospores and $99.3 \%$ of conidia germinated on unamended water agar. Except for a single ascospore of isolate W277 which was collected in 1998, no other ascospores and no conidia of baseline isolates germinated on water agar amended with boscalid at $10.0 \mathrm{mg} /$ liter (data not shown). Conidia of five isolates did not germinate with boscalid at $1.0 \mathrm{mg} / \mathrm{liter}$. Conidia of 10 isolates and ascospores of 20 isolates germinated at $1.0 \mathrm{mg} / \mathrm{liter}$ ( $t$ tests of leastsquare means compared with $0, P \leq 0.05$ ). There was no interaction between spore type and isolate $(P=0.72)$. Mean relative germination percentages of $25.2 \%$ for ascospores and $5.2 \%$ for conidia differed significantly $(P<0.0001)$.

Mean germination of ascospores and conidia of 10 isolates collected in 2005 that had been exposed to boscalid for $\leq 3$ years was 99.7 and $99.0 \%$, respectively, on unamended water agar. All 10 isolates were sensitive to boscalid. Conidia of three isolates did not germinate with boscalid at $1.0 \mathrm{mg} /$ liter but ascospores of all isolates did. Relative germination of conidia of four other isolates was $\leq 1.3 \%$ and not significantly greater than 0 ( $t$ tests of least-square means, $P=0.05$ ). Although there was an interaction between spore type and isolate with boscalid at $1.0 \mathrm{mg} / \mathrm{liter}(P=0.008)$, pairwise comparisons of relative germination between ascospores and conidia differed for all 10 isolates $(P \leq 0.04)$. Mean relative germination percentages of $16.9 \%$ for ascospores and $2.2 \%$ for conidia differed significantly $(P<0.0001)$. No spores germinated on water agar amended with boscalid at $10.0 \mathrm{mg} / \mathrm{liter}$.

Table 2. Comparison of virulence of 12 isolates of Didymella bryoniae that differed in $50 \%$ effective concentration $\left(\mathrm{EC}_{50}\right)$ values for boscalid and were inoculated onto muskmelon seedlings treated with boscalid, pyraclostrobin, pyraclostrobin + boscalid, or water in a greenhouse $\mathrm{e}^{\mathrm{x}}$

\begin{tabular}{|c|c|c|c|c|c|c|c|c|}
\hline \multirow[b]{2}{*}{ Isolate } & \multirow[b]{2}{*}{ County } & \multicolumn{3}{|c|}{ Boscalid EC $_{50}(\mathrm{mg} /$ liter $)$} & \multicolumn{2}{|c|}{ Inoculum $\left(10^{6} / \mathrm{ml}\right)$} & \multirow[b]{2}{*}{ DS $(\%)^{y}$} & \multirow[b]{2}{*}{$\operatorname{RDS}(\%)^{z}$} \\
\hline & & Con & Asco & Con + Asco & Con & Asco & & \\
\hline \multicolumn{9}{|l|}{ Group 1} \\
\hline W681 & Barnwell & 0.19 & 3.20 & 0.61 & 0.4 & 1.6 & $11.0 \mathrm{~b}$ & $85.0 \mathrm{a}$ \\
\hline W711 & Barnwell & 0.39 & 5.87 & 1.37 & 0.2 & 1.8 & $12.9 \mathrm{~b}$ & $60.0 \mathrm{a}$ \\
\hline W709 & Barnwell & $>10.00$ & $>10.00$ & $>10.00$ & 0.4 & 1.6 & $9.2 \mathrm{~b}$ & $42.2 \mathrm{a}$ \\
\hline W771 & Bamberg & 1.21 & 5.51 & 2.41 & 0.2 & 1.8 & $39.7 \mathrm{ab}$ & $75.5 \mathrm{a}$ \\
\hline W764 & Bamberg & 1.61 & 9.19 & 4.08 & 0.2 & 1.6 & $56.1 \mathrm{a}$ & $69.5 \mathrm{a}$ \\
\hline W766 & Bamberg & $>10.00$ & $>10.00$ & $>10.00$ & 0.7 & 1.3 & $29.2 \mathrm{ab}$ & $57.5 \mathrm{a}$ \\
\hline \multicolumn{9}{|l|}{ Group2 } \\
\hline W678 & Barnwell & 0.31 & 1.38 & 0.61 & 0.0 & 1.0 & $18.6 \mathrm{a}$ & $76.0 \mathrm{a}$ \\
\hline W708 & Barnwell & 0.74 & $>10.00$ & 2.65 & 0.0 & 1.5 & $14.8 \mathrm{a}$ & $69.6 \mathrm{a}$ \\
\hline W686 & Barnwell & $>10.00$ & $>10.00$ & $>10.00$ & 0.3 & 1.5 & $29.5 \mathrm{a}$ & $72.7 \mathrm{a}$ \\
\hline W798 & Bamberg & 0.12 & 2.50 & 0.62 & 0.0 & 1.5 & $11.3 \mathrm{a}$ & $68.6 \mathrm{a}$ \\
\hline W773 & Bamberg & 4.58 & 6.09 & 5.33 & 0.2 & 1.7 & $9.2 \mathrm{a}$ & $64.0 \mathrm{a}$ \\
\hline W800 & Bamberg & $>10.00$ & $>10.00$ & $>10.00$ & 0.4 & 1.1 & $10.5 \mathrm{a}$ & $73.3 \mathrm{a}$ \\
\hline
\end{tabular}

${ }^{\mathrm{x}}$ Con $=$ conidia, Asco $=$ ascospores. Means within groups followed by the same letter are not significantly different $(t$ tests, $P=0.01)$.

${ }^{y}$ Disease severity (DS). Mean across two trials, four fungicide treatments (three fungicides and the water control), three replications, and three seedlings rated individually per replication. Values shown are back-transformed least-square means from arcsin-square root transformed values used in analysis of variance.

${ }^{\mathrm{z}}$ Relative disease severity (RDS) $=$ percentage disease severity on fungicide-treated seedlings divided by the percentage disease severity on the water control. Means were calculated across two trials, three fungicides, three replications, and three seedlings rated individually per replication. Values shown are back-transformed least-square means from arcsin-square root transformed values used in analysis of variance. 
Varying percentages of ascospores and conidia of 37 isolates collected in 2009 from watermelon sprayed with Pristine germinated on water agar amended with boscalid at $10 \mathrm{mg} / \mathrm{liter}$ (Table 1). Mean germination of ascospores and conidia on unamended water agar was 99.9 and $98.3 \%$, respectively. With boscalid at 10.0 $\mathrm{mg} / \mathrm{liter}$, there was no interaction between spore type and isolate $(P$ $=0.96$ ). Mean relative germination percentage at $10.0 \mathrm{mg} /$ liter was higher for ascospores (29.0\%) than for conidia (11.7\%) $(P<$ $0.0001)$. Relative germination percentage for conidia of five isolates was not significantly greater than 0 , whereas the relative germination percentage for ascospores for all isolates was greater than $0(t$ tests of least-square means, $P=0.05)$.

$\mathbf{E C}_{50}$ values for boscalid. Because ascospores consistently germinated more frequently than conidia on boscalid-amended media, it was not clear which spore type should be used to calculate $\mathrm{EC}_{50}$ values. Therefore, $\mathrm{EC}_{50}$ values were calculated with relative germination of conidia and ascospores separately and with mean relative germination across both spore types on media amended with four concentrations of boscalid. Isolates with an $\mathrm{EC}_{50} \leq 1.0 \mathrm{mg} / \mathrm{liter}$ were considered to be sensitive, because no conidia and only 1 ascospore of 1 of 31 baseline isolates germinated with boscalid at $10.0 \mathrm{mg} / \mathrm{liter}$. Isolates with an $\mathrm{EC}_{50}>1.0$ and $\leq 10.0 \mathrm{mg} / \mathrm{liter}$ were considered moderately insensitive, and isolates with an $\mathrm{EC}_{50}>10.0$ were highly insensitive. At least $3 \%$ of conidia and $13 \%$ of ascospores of all insensitive isolates germinated with boscalid at 10.0 $\mathrm{mg} / \mathrm{liter}$ (data not shown). Mean and median $\mathrm{EC}_{50}$ values and the range of values for the 68 isolates discussed above (the three groups of isolates that were not exposed, minimally exposed, or repeatedly exposed) were largest with ascospores, intermediate with both spore types, and lowest with conidia (Table 1). All 31 isolates collected prior to or in 2005 had $\mathrm{EC}_{50}$ values $<1.0$ based on germination of ascospores, conidia, and both spore types and were sensitive to boscalid.

The most variation among spore types was observed with 37 of the 135 isolates collected in 2009 from South Carolina watermelon fields. The $\mathrm{EC}_{50}$ values of these 37 isolates were $\leq 10 \mathrm{mg} / \mathrm{liter}$ but still within the range of boscalid concentrations used. Based on conidia germination, 23 (62\%) of these isolates were judged to be sensitive to boscalid, with an $\mathrm{EC}_{50} \leq 1.0 \mathrm{mg} / \mathrm{liter}$. However, with ascospore germination and with mean germination across conidia and ascospores, $<25 \%$ of the isolates were classified as sensitive and $\geq 75 \%$ of the isolates were considered insensitive (Table 1).

With another group of 68 insensitive isolates selected randomly from the remaining 98 (of 135) 2009 isolates, 1 (1.5\%), 30 (44\%), and $14(21 \%)$ isolates had $\mathrm{EC}_{50}$ values $>1.0$ and $\leq 10 \mathrm{mg} / \mathrm{liter}$ based on germination of ascospores, conidia, and both spore types, respectively. Of these 68 isolates, 38 were classified as highly insensitive, with $\mathrm{EC}_{50}$ values $>10.0$ based on conidia germination. These isolates also were highly insensitive based on germination of ascospores and both spore types, except one isolate that had an $\mathrm{EC}_{50}$ value of 9.96 based on ascospore germination.

Greenhouse experiments. All 12 isolates of $D$. bryoniae collected from Bamberg or Barnwell counties in 2009 and tested in the greenhouse caused gummy stem blight on muskmelon seedlings previously treated with water, boscalid, pyraclostrobin, or boscalid + pyraclostrobin (Table 2 ). No symptoms developed on any seedlings in any trial that were sprayed with water and then with sucrose-casein. One noninoculated control seedling in one pot sprayed with boscalid + pyraclostrobin in the second trial had one small leaf spot from which $D$. bryoniae was recovered. Disease severity on inoculated seedlings sprayed with water ranged from 17 to $72 \%$ for the 12 isolates. Levels of disease severity in the four fungicide treatments were not affected by differing amounts of ascospores or conidia in the inoculum suspensions, based on correlation analysis (data not shown).

Isolates were selected for greenhouse testing because their $\mathrm{EC}_{50}$ values based on conidial germination indicated they were sensitive, moderately insensitive, or highly insensitive to boscalid in vitro. With both groups of isolates, there was a highly significant effect of fungicide treatment on the severity of gummy stem blight (Table 3 ). In trial 1 with the first group of isolates and in trial 2 with the second group of isolates, all three fungicides reduced severity of gummy stem blight compared with the water control but did not differ from each other (Fig. 1) With the first group of isolates in trial 2, boscalid + pyraclostrobin had less gummy stem blight than the water control and boscalid (Fig. 1). With the second group of isolates, fungicides did not differ from the water control in trial 1 (Fig. 1). Disease severity varied among isolates in the first group, whereas isolates in the second group did not differ from each other (Tables 2 and 3). With both groups of isolates, there was no isolate-fungicide interaction, which indicated that the response of all isolates to fungicide treatments was similar, despite the expected

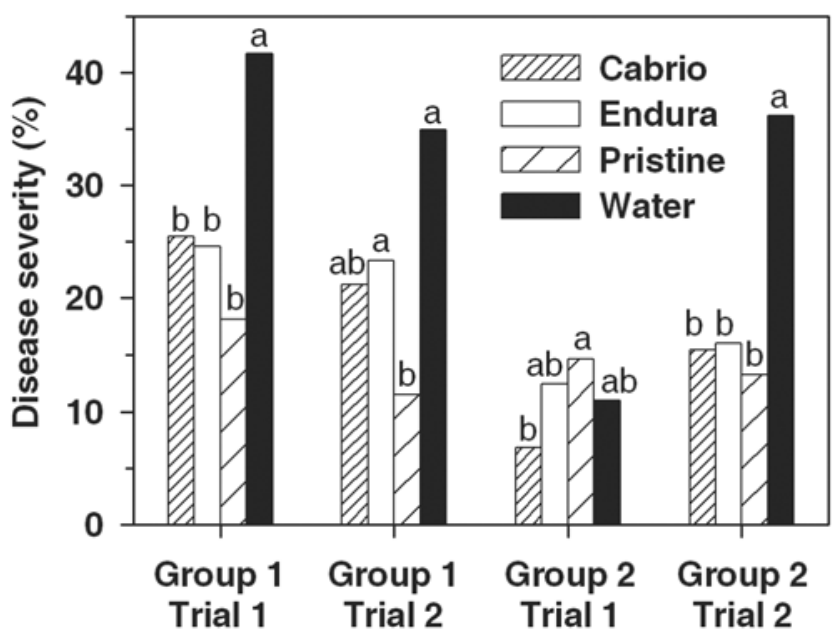

Fig. 1. Mean severity of gummy stem blight on muskmelon seedlings treated with fungicides the day before inoculation with 1 of 12 isolates of Didymella bryoniae. The trial-fungicide interaction was significant for group 2. Means within groups and trials followed by the same letter are not significantly different ( $t$ tests, $P=0.01$ ).

Table 3. Analysis of variance with severity of gummy stem blight caused by 12 isolates of Didymella bryoniae on muskmelon seedlings treated with pyraclostrobin, boscalid, pyraclostrobin + boscalid, or water in a greenhouse ${ }^{z}$

\begin{tabular}{|c|c|c|c|c|c|c|}
\hline \multirow[b]{2}{*}{ Source of variation } & \multicolumn{2}{|c|}{ Degrees of freedom } & \multicolumn{2}{|c|}{ Group 1} & \multicolumn{2}{|c|}{ Group 2} \\
\hline & Numerator & Denominator & $F$ & Prob $>F$ & $F$ & Prob $>F$ \\
\hline Trial & 1 & 21 & 0.43 & 0.52 & 1.60 & 0.22 \\
\hline Isolate & 5 & 21 & 4.28 & 0.0077 & 0.70 & 0.63 \\
\hline Trial $\times$ isolate & 5 & 21 & 0.57 & 0.72 & 1.94 & 0.13 \\
\hline Fungicide & 3 & 63 & 17.68 & $<0.0001$ & 9.09 & $<0.0001$ \\
\hline Trial $\times$ fungicide & 3 & 63 & 0.38 & 0.76 & 10.34 & $<0.0001$ \\
\hline Isolate $\times$ fungicide & 15 & 63 & 0.65 & 0.82 & 0.91 & 0.56 \\
\hline Trial $\times$ isolate $\times$ fungicide & 15 & 63 & 1.40 & 0.17 & 1.04 & 0.43 \\
\hline
\end{tabular}

${ }^{\mathrm{z}} \mathrm{Six}$ isolates, three from one farm in Bamberg County and one farm in Barnwell County, $\mathrm{SC}$, that differed in preliminary $50 \%$ effective concentration (EC $\mathrm{E}_{50}$ ) values for boscalid based on conidial germination on boscalid-amended media were included in each group. Within each group, two isolates (one from each farm) were judged to be highly insensitive and the other four isolates were sensitive or moderately insensitive to boscalid in vitro. $F=F$ value and Prob $=$ probability. 
differential response to boscalid, based on conidia germination in vitro (Table 3 ).

Relative disease severity was calculated for each isolate to assess disease development on fungicide-treated plants relative to the water control, as was done with spore germination in vitro (19). With both groups of isolates, there were no significant differences between the two trials, no significant differences among the six isolates within a group, and no significant interactions, including no isolate-fungicide interaction (Table 4). The lack of an isolatefungicide interaction and the lack of a significant isolate effect after differences in virulence among isolates were accounted for indicated that the response of all isolates to the three fungicides was similar (Table 2). Mean relative disease severity for each isolate was significantly greater than 0 with each of the three fungicides ( $t$ tests, $P \leq 0.002$ ). Thus, the three fungicides did not suppress gummy stem blight development by any of the 12 isolates.

With the first group of isolates, effects of treatment were significant (Table 4) because relative disease severity was greater on boscalid-treated plants $(74.8 \%)$ than on plants treated with boscalid + pyraclostrobin $(54.7 \%)(t$ tests of least-squares means, $P=0.01$ ). Mean relative disease severity on pyraclostrobin-treated plants was intermediate $(66.7 \%)$ and did not differ from the values for the other two fungicides. With the second group of isolates, relative disease severity averaged across all treatments was higher in trial 1 $(81 \%)$ than in trial $2(51 \%)$ (Table 4$)$ but there were no significant interactions of treatment-trial. Mean relative disease severity on seedlings treated with boscalid, boscalid + pyraclostrobin, or pyraclostrobin was $62.4,76.0$, and $73.4 \%$, respectively, of disease severity on the water control (set to $100 \%$ ) and did not differ among fungicides.

Sensitivity of isolates from South Carolina to boscalid. Based on the results of in vitro and greenhouse experiments, sensitivity to boscalid was evaluated based on $\mathrm{EC}_{50}$ values calculated with mean relative germination of ascospores and conidia together. Isolates with $\mathrm{EC}_{50}$ values $>1.0 \mathrm{mg} / \mathrm{liter}$ were considered insensitive to boscalid. All five isolates of $D$. bryoniae collected in two watermelon fields in 2008 were highly insensitive to boscalid with $\mathrm{EC}_{50}$ values $>10 \mathrm{mg} / \mathrm{liter}$. Of the 135 field isolates collected in 2009,15 $(11 \%)$ were sensitive (i.e., had $\mathrm{EC}_{50}$ values $<1.0 \mathrm{mg} / \mathrm{liter}$ ) and the remaining $120(89 \%)$ were insensitive. Ascospores and conidia of these sensitive isolates that had been exposed to boscalid had higher relative germination (64.1 and $45.4 \%$, respectively) than baseline isolates at $1.0 \mathrm{mg} / \mathrm{liter}$. At $10.0 \mathrm{mg} / \mathrm{liter}$, relative germination averaged $14.0 \%$ for ascospores and $4.4 \%$ for conidia. Of the insensitive isolates, 54 isolates were moderately insensitive (i.e., had $\mathrm{EC}_{50}$ values $>1.0 \mathrm{mg} / \mathrm{liter}$ and $<10.0 \mathrm{mg} / \mathrm{liter}$ ) and 66 isolates ( $49 \%$ of the total and $55 \%$ of the insensitive isolates) were highly insensitive, with $\mathrm{EC}_{50}$ values $>10.0 \mathrm{mg} / \mathrm{liter}$. The frequency distributions of isolates on three farms in Hampton, Bamberg, and Barnwell Counties were similar, and a majority of the isolates were highly insensitive (Fig. 2). On the farm in Colleton County, from which only six isolates were recovered, half of the isolates were sensitive. In the research plots in which Pristine had been used in rotation with other fungicides, the majority of the isolates were moderately insensitive. Overall, $92.6 \%$ of the South Carolina isolates collected in watermelon fields in 2008 and 2009 were insensitive. Insensitive isolates also were found in 2006 and 2009 in collections of isolates from the same greenhouse in South Carolina. In the 2006 collection of 11 isolates, 3 were insensitive and, in the 2009 collection of 19 isolates, 16 were insensitive (Table 1). Thus, $63 \%$ of the isolates from the greenhouse were insensitive. Of the 170 isolates collected in South Carolina since 2006, 84.7\% (144 isolates) were insensitive to boscalid.

\section{Discussion}

This is the first report of differential sensitivity to a fungicide between spore types in D. bryoniae. Ascospores of D. bryoniae germinated more frequently (1.6 to 8.4 times) on boscalidamended media than conidia did. Differences in sensitivity of ascospores and conidia of $D$. bryoniae to boscalid were apparent in baseline isolates and in exposed isolates that were sensitive, moderately insensitive, and highly insensitive. Ascospores were not examined in other previously published boscalid-sensitivity studies with $D$. bryoniae or the related species, D. rabiei $(38,39,46)$. Ascospores and conidia of Leptosphaeria maculans, another ascomycete pathogen in the family Pleosporales, also responded differently to fungicides (11). Ascospores of L. maculans were insensitive to low concentrations $(\leq 4 \mu \mathrm{g} / \mathrm{ml})$ of flusilazole, tebuconazole, and benomyl, whereas conidia were sensitive. At least $98 \%$ of both ascospores and conidia of D. bryoniae had

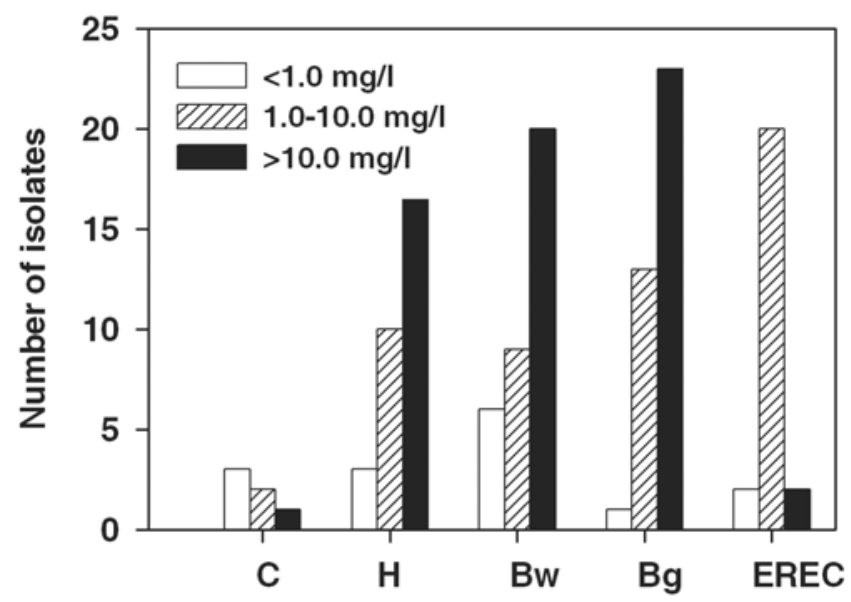

Fig. 2. Frequency distribution of boscalid $50 \%$ effective concentration $\left(E C_{50}\right)$ values calculated from germination of ascospores and conidia of 135 isolates of Didymella bryoniae collected from watermelon on four farms in Bamberg (Bg), Barnwell (Bw), Colleton (C), and Hampton (H) Counties, SC, and from research plots (EREC) in Barnwell County, SC, in 2009.

Table 4. Analysis of variance for relative disease severity of 12 isolates of Didymella bryoniae inoculated on muskmelon seedlings treated with pyraclostrobin, boscalid or pyraclostrobin + boscalid in a greenhouse ${ }^{\mathrm{z}}$

\begin{tabular}{|c|c|c|c|c|c|c|}
\hline \multirow[b]{2}{*}{ Source of variation } & \multicolumn{2}{|c|}{ Degrees of freedom } & \multicolumn{2}{|c|}{ Group 1} & \multicolumn{2}{|c|}{ Group 2} \\
\hline & Numerator & Denominator & $\boldsymbol{F}$ & Prob $>F$ & $F$ & Prob $>F$ \\
\hline Trial & 1 & 18 & 0.06 & 0.80 & 12.24 & 0.0026 \\
\hline Isolate & 5 & 18 & 1.22 & 0.34 & 0.10 & 0.99 \\
\hline Trial $\times$ isolate & 5 & 18 & 2.46 & 0.07 & 1.48 & 0.24 \\
\hline Fungicide & 2 & 36 & 3.55 & 0.04 & 1.30 & 0.29 \\
\hline Trial $\times$ fungicide & 2 & 36 & 0.20 & 0.82 & 1.08 & 0.35 \\
\hline Isolate $\times$ fungicide & 10 & 36 & 0.84 & 0.59 & 1.29 & 0.27 \\
\hline Trial $\times$ isolate $\times$ fungicide & 10 & 36 & 1.82 & 0.09 & 1.20 & 0.32 \\
\hline
\end{tabular}

${ }^{\mathrm{z}}$ Relative disease severity $=$ percent disease severity on fungicide-treated seedlings divided by the percent disease severity on the water control. Six isolates, three from one farm in Bamberg County and one farm in Barnwell County, $\mathrm{SC}$, that differed in preliminary $50 \%$ effective concentration $\left(\mathrm{EC}_{50}\right)$ values for boscalid based on conidial germination on boscalid-amended media were included in each group. Within each group, two isolates (one from each farm) were judged to be highly insensitive and the other four isolates were sensitive or moderately insensitive to boscalid in vitro. $F=F$ value and Prob $=$ probability. 
germinated after $24 \mathrm{~h}$ on unamended water agar. Although ascospores of $D$. rabiei germinated more rapidly than conidia in another study, germination of both spore types on water agar reached a maximum after 12 to $24 \mathrm{~h}$ (41). Thus, it was very unlikely that the differences observed in sensitivity to boscalid between ascospores and conidia of D. bryoniae at $24 \mathrm{~h}$ were due to differences in germination rates. Whether differential sensitivity to boscalid is related to ascospores being two-celled is unknown. Fungicides decreased the number of germ tubes produced by L. maculans from terminal cells of the multicellular ascospores but not from interstitial cells (11). Sensitivity of ascospores and conidia of $D$. bryoniae to fungicides other than boscalid is being tested in additional experiments.

The potential exists for short-distance dispersal of fungicide-insensitive isolates of $D$. bryoniae via ascospore transport. Ascospores of Mycosphaerella graminicola, an ascomycete pathogen of wheat, that carried the strobilurin-insensitivity mutation G143A were detected up to $85 \mathrm{~m}$ from an infected crop treated with trifloxystrobin (14). All isolates of $D$. bryoniae used in this study readily formed ascospores and conidia on QPDA when cultured as described herein. In the field, D. bryoniae produced pseudothecia, asci, or ascospores on vegetative parts of 18 different cultivars of nine cultivated cucurbits (20). In another study, pseudothecia formed on overwintered muskmelon debris (18). Ascospores also were produced on cucumber debris inside and outside greenhouses (44). Ascospores of D. bryoniae were trapped in the air $1.2 \mathrm{~m}$ above a field of watermelon with gummy stem blight in Florida (34). How far ascospores of D. bryoniae are dispersed away from infected plants has not been determined.

The hypothesis tested in the greenhouse was that isolates of $D$. bryoniae with low $\mathrm{EC}_{50}$ values (based on conidial germination on boscalid-amended media) would show a different response on plants treated with boscalid than isolates with high $\mathrm{EC}_{50}$ values (i.e., they would have lower gummy stem blight severity ratings). Because there was no isolate-fungicide interaction for either percent severity or relative severity (adjusted for differences in virulence of isolates), all 12 isolates responded similarly to the fungicides regardless of $\mathrm{EC}_{50}$. Because more ascospores than conidia germinated when exposed to boscalid in vitro, the presence of ascospores in the inoculum suspensions of all isolates likely resulted in a substantial percentage of germinated spores and significant development of gummy stem blight on boscalid-treated seedlings. Isolates appeared to be more sensitive to boscalid in vitro than they were in the greenhouse, because fewer conidia than ascospores germinated on boscalid-amended media. Thus, calculating $\mathrm{EC}_{50}$ values based on conidia alone underestimated isolates' actual insensitivity to boscalid. This miscalculation had the largest impact on $\mathrm{EC}_{50}$ values for moderately insensitive isolates, which are the isolates of primary interest when insensitivity is first detected. Because D. bryoniae produces two types of spores in the field, both ascospores and conidia should be used when calculating $\mathrm{EC}_{50}$ values for boscalid.

The percentage of field isolates of $D$. bryoniae that were insensitive to boscalid was relatively similar in South Carolina (92\%) and Georgia (83.5\%) (40). The percentage may have been lower in Georgia due to different methods, because a single concentration ( $3 \mathrm{mg} / \mathrm{liter}$ ) and a mycelia growth assay were used. Baseline isolates from Georgia assayed with mycelia growth had a median $\mathrm{EC}_{50}$ of $0.055 \mu \mathrm{g} / \mathrm{ml}$, which also was lower than the values obtained with spore germination in the present study (38). Baseline $\mathrm{EC}_{50}$ values based on germination of conidia of $D$. rabiei ranged from 0.018 to $0.50 \mu \mathrm{g} / \mathrm{ml}$, with a mean of $0.19 \mu \mathrm{g} / \mathrm{ml}$ (46). This mean was slightly higher than the mean of $0.13 \mu \mathrm{g} / \mathrm{ml}$ based on conidia germination by $D$. bryoniae in the present study but still fell within the same order of magnitude.

In the greenhouse experiment, severity of gummy stem blight caused by one group of isolates was somewhat lower on plants treated with Pristine than on plants treated with either Cabrio or Endura; with the other group of isolates, there were no differences among the three fungicides. In a field naturally infested with stro- bilurin- and boscalid-insensitive isolates of D. bryoniae, gummy stem blight was severe and progressed similarly on watermelon plants treated with boscalid, pyraclostrobin, or boscalid + pyraclostrobin (21). Thus, Pristine may provide better control of gummy stem blight than boscalid or pyraclostrobin with some doubly insensitive isolates but this effect appears to be isolate dependent. However, the level of control observed in the greenhouse and field was not enough to prevent substantial yield loss if disease started during a critical period for fruit production (16).

Strobilurin-insensitive isolates of $D$. bryoniae previously were found in watermelon transplant-production greenhouses in Georgia (39) and South Carolina (19). Thus, there is a risk of spreading fungicide-insensitive isolates on transplants if transplants with symptoms of gummy stem blight are shipped to growers. The pollenizer watermelon seedlings from which the boscalid-insensitive isolates were obtained in 2006 were not distributed to growers because they were too severely diseased. The three farms in Bamberg, Barnwell, and Hampton Counties sampled in 2009 all obtained watermelon transplants from the greenhouse sampled in 2009. It is not known whether any of the transplants supplied to the three farms in 2009 had symptoms of gummy stem blight on them. It is interesting that the frequency distributions of $\mathrm{EC}_{50}$ values on the three farms were much more similar to each other than to the distributions on the farm in Colleton and the research plots, both of which were transplanted with seedlings from other sources. However, insensitive isolates of $D$. bryoniae were present on other farms in Bamberg and Barnwell Counties since 2008, and insensitive isolates also were found on the farm in Colleton and in the research plots. Thus, the role of transplants in dissemination of boscalid-insensitive isolates remains unclear.

Mixing fungicides with two different modes of action has been widely recommended as a strategy to prevent development of insensitivity to fungicides with site-specific modes of action, such as strobilurins and boscalid $(8,36)$. Strobilurin-insensitive isolates of D. bryoniae were present in Georgia and South Carolina 3 and 2 years, respectively, before Pristine was registered in 2003 (19,39). Applying Pristine to a strobilurin-insensitive population should have been equivalent to applying boscalid alone. If watermelon growers in Georgia and South Carolina began using Pristine in 2003 when it was registered, then insensitivity to boscalid developed after 5 and 6 years of use, respectively $(25,38)$. This period of time is twice as long as the period from the registration of strobilurins as "stand-alone" products on cucurbits in 1998 to the first detection of strobilurin-insensitive isolates of D. bryoniae in 2000 $(19,39)$. It appears that the mixture of boscalid with pyraclostrobin may have slowed development of insensitivity to boscalid in $D$. bryoniae, possibly due to uneven distribution of strobilurin-insensitive isolates or the occurrence of mixed populations of sensitive and insensitive isolates $(19,39)$.

A new member of FRAC group 7 (the succinate-dehydrogenase inhibitors) is fluopyram (Luna SC500; Bayer CropScience, Research Triangle Park, NC), a pyridinyl-ethyl-benzamide. Fluopyram apparently binds to a different target site in ascomycete fungi than boscalid does, because it was effective against boscalidinsensitive isolates of three cucurbit pathogens, including $D$. bryoniae $(15,24)$. Formulations of fluopyram to be registered on cucurbits to control gummy stem blight and other diseases will include either trifloxystrobin or tebuconazole (13). Because boscalid insensitivity appeared after insensitivity had developed to its formulation partner, pyraclostrobin, combining fluopyram with trifloxystrobin might not prevent insensitivity to fluopyram, because cross-resistance exists among strobilurin fungicides (47). Mixing fluopyram with tebuconazole, however, should be an effective strategy to delay or prevent insensitivity, because tebuconazole is effective against isolates of $D$. bryoniae that are insensitive to boscalid and pyraclostrobin $(23,32)$.

\section{Acknowledgments}

This material is based upon work supported by NIFA United States Department of Agriculture under project numbers SC-1700294 and 2008-34287-19425, 
the South Carolina Department of Agriculture through the Specialty Crops Block Grant Program Agreement number 12-25-B-0948, and the South Carolina Watermelon Association. I thank E. L. Fillippeli, V. B. DuBose, and G. V. Baccari for technical assistance.

\section{Literature Cited}

1. Anonymous. 2005. Crop Profile for Watermelons in North Carolina. National Information System for the Regional IPM Centers.

2. Avenot, H. F., Morgan, D. P., and Michailides, T. J. 2008. Resistance to pyraclostrobin, boscalid and multiple resistance to Pristine (pyraclostrobin + boscalid) fungicide in Alternaria alternata causing Alternaria late blight of pistachios in California. Plant Pathol. 57:135-140.

3. Avenot, H. F., Sellam, A., Karaoglanidis, G., and Michailides, T. J. 2008. Characterization of mutations in the iron-sulphur subunit of succinate dehydrogenase correlating with boscalid resistance in Alternaria alternata from California pistachio. Phytopathology 98:736-742.

4. Avenot, H. F., Thomas, A., Gitaitis, R. D., Langston, D. B., and Stevenson, K. L. 2010. Molecular characterization of resistance to boscalid and penthiopyrad in Didymella bryoniae isolates collected from Georgia watermelon fields. (Abstr.) Phytopathology 100:S9.

5. Aveskamp, M. M., de Gruyter, J., Woudenberg, J. H. C., Verkley, G. J. M., and Crous, P. W. 2010. Highlights of the Didymellaceae: a polyphasic approach to characterise Phoma and related pleosporalean genera. Stud. Mycol. 65:1-60.

6. Bartlett, D. W., Clough, J. M., Godwin, J. R., Hall, A. A., Hamar, M., and Parr-Dobrzanski, B. 2002. The strobilurin fungicides. Pest Manage. Sci. 58:649-662.

7. Bergstrom, G. C., Knavel, D. E., and Kuć, J. 1982. Role of insect injury and powdery mildew in the epidemiology of the gummy stem blight disease of cucurbits. Plant Dis. 66:683-686.

8. Brent, K. J., and Holloman, D. W. 2007. Fungicide resistance in crop pathogens: how can it be managed? FRAC Monogr. No. 1, 2nd ed. Fungicide Resistance Action Committee, Croplife International.

9. Chiu, W. F., and Walker, J. C. 1949. Morphology and variability of the cucurbit black-rot fungus. J. Agric. Res. 78:81-102.

10. de Neergaard, E. 1989. Studies of Didymella bryoniae (Auersw.) Rehm: development in the host. J. Phytopathol. 127:107-115.

11. Eckert, M. R., Rossall, S., Selleyc, A., and Fitt, B. D. L. 2010. Effects of fungicides on in vitro spore germination and mycelial growth of the phytopathogens Leptosphaeria maculans and L. biglobosa (Phoma stem canker of oilseed rape). Pest Manage. Sci. 66:396-405.

12. Egel, D. S., and Hoke, S. 2010. Management of cucurbit powdery mildew and fungicide insensitive gummy stem blight. Plant Dis. Manage. Rep. No. 4:V137. Online publication. doi:10.1094/PDMR04.

13. Environmental Protection Agency. 2009. Pesticide Products; Registration Applications. Federal Register 74:67207-67209.

14. Fraaije, B. A., Cools, H. J., Fountaine, J., Lovell, D. J., Motteram, J., West, J. S., and Lucas, J. A. 2005. Role of ascospores in further spread of QoI-resistant cytochrome $b$ alleles (G143A) in field populations of Mycosphaerella graminicola. Phytopathology 95:933-941.

15. Ishii, H., Miyamoto, T., Ushio, S., and Kakishima, M. 2011. Lack of crossresistance to a novel succinate dehydrogenase inhibitor, fluopyram, in highly boscalid-resistant isolates of Corynespora cassiicola and Podosphaera xanthii. Pest Manage. Sci. 67:474-482.

16. Keinath, A. P. 2000. Effect of protectant fungicide application schedules on gummy stem blight epidemics and marketable yield of watermelon. Plant Dis. $84: 254-260$

17. Keinath, A. P. 2002. Survival of Didymella bryoniae in buried watermelon vines in South Carolina. Plant Dis. 38:32-38.

18. Keinath, A. P. 2008. Survival of Didymella bryoniae in infested muskmelon crowns in South Carolina. Plant Dis. 92:1223-1228.

19. Keinath, A. P. 2009. Sensitivity to azoxystrobin in Didymella bryoniae isolates collected before and after field use of strobilurin fungicides. Pest Manage. Sci. 65:1090-1096.

20. Keinath, A. P. 2010. Susceptibility of cucurbit species to gummy stem blight and their suitability for reproduction by Didymella bryoniae. Cucurbitaceae 2010 Proc.:2-5.

21. Keinath, A. P., Baccari, G. V., and DuBose, V. B. 2010. Evaluation of Pristine and its components against pyraclostrobin- and boscalid-insensitive $D i$ dymella bryoniae, 2009. Plant Dis. Manage. Rep. No. 4:V013. Online publication. doi:10.1094/PDMR04

22. Keinath, A. P., and DuBose, V. B. 2004. Evaluation of fungicides for prevention and management of powdery mildew on watermelon. Crop Prot. 23:35-42.
23. Keinath, A. P., and DuBose, V. B. 2009. Evaluation of triazoles and other fungicides for control of gummy stem blight on watermelon, 2008. Plant Dis. Manage. Rep. No. 3:V034. Online publication. doi:10.1094/PDMR03.

24. Keinath, A. P., DuBose, V. B., and Baccari, G. V., 2011. Evaluation of Catamaran and triazole fungicides alternated with mancozeb to control gummy stem blight on watermelon, 2010. Plant Dis. Manage. Rep. No. 5:V081. Online publication. doi:10.1094/PDMR05.

25. Keinath, A. P., DuBose, V., and Walters, E. 2009. First report from South Carolina of boscalid-insensitive isolates of Didymella bryoniae on fieldgrown watermelon treated with boscalid-pyraclostrobin. (Abstr.) Phytopathology 99:S62.

26. Keinath, A. P., Farnham, M. W., and Zitter, T. A. 1995. Morphological, pathological, and genetic differentiation of Didymella bryoniae and Phoma spp. isolated from cucurbits. Phytopathology 85:364-369.

27. Keon, J. P. R., White, G.A., and Hargreaves, J.A. 1991. Isolation, characterization and sequence of a gene conferring resistance to the systemic fungicide carboxin from the maize smut pathogen, Ustilago maydis. Curr. Genet. 19:475-481.

28. Kothera, R. T., Keinath, A. P., Dean, R. A., and Farnham, M. W. 2003 AFLP analysis of a worldwide collection of Didymella bryoniae. Mycol. Res. 107:297-304.

29. Langston, D. B., Jr., and Sanders, F. H., Jr. 2008. Evaluation of fungicides for suppressive gummy stem blight in Georgia watermelons, 2007. Plant Dis. Manage. Rep. 2:V166. Online publication. doi:10.1094/PDMR02.

30. Miller, M. E., Saldana, R., and Bruton, B. D. 2006. Management of gummy stem blight of muskmelon in south Texas. (Abstr.) Phytopathology 96:S79.

31. Olaya, G., and Holm, A. 2001. Sensitivity of Didymella bryoniae isolates to azoxystrobin. (Abstr.) Phytopathology 91:S67.

32. Sanders, Jr., F. H., and Langston, Jr., D. B. 2010. Evaluation of fungicide sprays on gummy stem blight of watermelon in Georgia I, 2009. Plant Dis. Manage. Rep. 4:V152. Online publication. doi:10.1094/PDMR04.

33. Schenck, N. C. 1968. Incidence of airborne fungus spores over watermelon field in Florida. Phytopathology 58:91-94.

34. Schenck, N. C. 1968. Epidemiology of gummy stem blight (Mycosphaerella citrullina) on watermelon: ascospore incidence and disease development. Phytopathology 58:1420-1422.

35. Seebold, K. W., Jr., and Langston, D. B., Jr. 2004. Evaluation of boscalid for control of gummy stem blight on watermelon. Fungic. Nematicide Tests 59:V051. Online publication. doi:10.1094/FN59.

36. Staub, T. 1991. Fungicide resistance: practical experience with antiresistance strategies and the role of integrated use. Annu. Rev. Phytopathol. 29:421-442.

37. Steele, R. G. D., and Torrie, J. H. 1980. Principles and Procedures of Statistics: A Biometrical Approach, 2nd ed. McGraw Hill Book Company, New York.

38. Stevenson, K. L., Langston, D. B., and Sanders, F. 2008. Baseline sensitivity and evidence of resistance to boscalid in Didymella bryoniae. (Abstr.) Phytopathology 98:S151.

39. Stevenson, K. L., Langston, D. B., Jr., and Seebold, K. W. 2004. Resistance to azoxystrobin in the gummy stem blight pathogen documented in Georgia. Plant Health Progress. Online publication. doi:10.1094/PHP-2004-1207-01RS

40. Thomas, A., Stevenson, K. L., and Langston, D. B. 2010. Sensitivity of Didymella bryoniae to DMI and carboxamide fungicides. (Abstr.) Phytopathology 100:S126.

41. Trapero-Casas, A., and Kaiser, W. J. 2007. Differences between ascospores and conidia of Didymella rabiei in spore germination and infection of chickpea. Phytopathology 97:1600-1607.

42. USDA, National Agricultural Statistics Service. 2008. Agricultural Chemical Use Database. Online.

43. USDA, National Agricultural Statistics Service. 2009. 2007 Census of Agriculture, South Carolina State and County Data. Vol. 1, Geographic Area Series, Part 40. AC-07-A-40.

44. van Steekelenburg, N. A. M. 1983. Epidemiological aspects of Didymella bryoniae, the cause of stem and fruit rot of cucumber. Neth. J. Plant Pathol. 89:75-86.

45. Wiant, J. S. 1945. Mycosphaerella black rot of cucurbits. J. Agric. Res. $71: 193-213$

46. Wise, K. A., Bradley, C. A., Pasche, J. S., Gudmestad, N. C., Dugan, F. M., and Chen, W. 2008. Baseline sensitivity of Ascochyta rabiei to azoxystrobin, pyraclostrobin, and boscalid. Plant Dis. 92:295-300.

47. Wong, F. P., Midland, S. L., and de la Cerda, K. A. 2007. Occurrence and distribution of QoI-resistant isolates of Colletotrichum cereale from annual bluegrass in California. Plant Dis.91:1536-1546. 